\title{
Effects of covid-19 on poultry production in south-east agro-ecological zone of
} Nigeria

${ }^{* 1}$ Esiegwu, A. C. and ${ }^{2}$ Ejike, R. D.

1. Department of Animal Science and Fisheries, Imo State University, P. M. B. 2000 Owerri-Nigeria

2. Department of Agricultural Economics, Extension and Rural Development, Imo State University, P. M. B. 2000 Owerri-Nigeria

Abstract *Corresponding author: arthuresiegwu@yahoo.com; 08032457629

This study investigated the effects of Covid-19 pandemic on poultry production in SouthEast, Nigeria. Multistage and purposive sampling techniques were used to select a total of 150 respondents for the study. The instruments for data collection was questionnaire and interview guide or schedule Focus Group Discussion (FGD) and In-depth Interview (IDI) of actors in the poultry sub-sectors were also used. Qualitative method was used for data analysis. Data collected were analyzed using both mean score analysis and content analysis. The results of the study showed that all the items considered attribute of the effects of Covid19 as perceived by the respondents turned out positive with an accepted mean values above 2.5 except for the attribute 'Covid-19 pandemic have affected the way I relate to my customers' which gave mean score value (2.4) below the cut-off mark. The study concluded that covid-19 pandemic had a negative impact on the poultry industry during the period under review. It resulted in scarcity of inputs and high cost offeed ingredients leading to high cost of production and high selling price. It also led to difficulty in accessing the markets leading to dumping of products and egg glut. It was recommended amongst others that government should incentivise the production of input materials (such as maize, soyabean, etc) especially feed production through an effective input subsidization mechanism to ensure cost-effective production of the various poultry subsectors.

Keywords: Covid-19, Poultry production, South-east Nigeria.

\section{Effets du covid-19 sur la production de volaille dans la zone agro-écologique du sud- est du Nigéria}

\section{Résumé}

Cette étude a examiné les effets de la pandémie de Covid-19 sur la production de volaille dans le sud-est du Nigéria. Des techniques d'échantillonnage à plusieurs degrés et téléologiques ont été utilisées pour sélectionner un total de 150 répondants pour l'étude. Les instruments de collecte de données étaient un questionnaire et un guide d'entretien ou un calendrier. Des discussions de groupe de discussion (FGD) et des entretiens approfondis (IDI) des acteurs des sous-secteurs de la volaille ont également été utilisés. Une méthode qualitative a été utilisée pour l'analyse des données. Les données collectées ont été analysées en utilisant à la fois l'analyse du score moyen et l'analyse du contenu. Les résultats de l'étude ont montré que tous les éléments considérés comme attribut des effets de Covid-19 tels que perçus par les répondants se sont révélés positifs avec des valeurs moyennes acceptées supérieures à 2,5, à l'exception de l'attribut "La pandémie de Covid-19 a affecté la façon dont je me rapporte à mes clients qui ont donné une valeur de score moyenne $(2,4)$ en dessous du seuil. L'étude a conclu que la pandémie de covid-19 avait eu un impact négatif sur l'industrie de la volaille au cours de la période considérée. Cela a entraîné une raréfaction 


\section{Effect of COVID-19 on poultry production in south east agro-ecological zone of Nigeria}

des intrants et un coût élevé des ingrédients alimentaires, entraînant un coût de production élevé et des prix de vente élevés. Cela a également entraîné des difficultés d'accès aux marchés, ce qui a conduit au dumping des produits et à la surabondance d'œufs. Il a été recommandé, entre autres, que le gouvernement encourage la production d'intrants (comme le maïs, le soja, etc.), en particulier la production d'aliments pour animaux grâce à un mécanisme efficace de subvention des intrants pour assurer une production rentable des divers sous-secteurs de la volaille.

Mots clés: Covid-19, production avicole, effet, sud-est, Nigéria.

\section{Introduction}

The current wave of Coronavirus, COVID19 pandemic has really distressed the world causing public health hazards. In Nigeria, its economic implication is very high as a result of the lock down rule. The livestock sector which, is the major source of protein supply to the masses suffered high level of distress ranging from lack of inputs, high cost of inputs and lack of market access for producers due to lockdown. The World Health Organization (WHO) announced the outbreak of a new Coronavirus (SARS$\mathrm{CoV}-2)$ at the beginning of the year 2020(Adhikari et al., 2020). According to WHO, the disease was first reported in the city of Wuhan, China, in December 2019(Adhikari et al., 2020). The disease has continued to spread to over 190 countries (Congressional Research Service., 2020). Although the Covid-19 disease broke out in China, the first confirmed case of COVID-19 in Nigeria was detected in a traveller who arrived in Lagos from Europe on February 27, 2020 (NCDC, 2020). Symptoms of Covid-19 infection include; fever, dry cough, shortness of breath or difficulty in breathing, muscle aches, headache, sore throat, or diarrhoea, runny nose and tiredness (NCDC, 2020b). Department of Health, 2020). As at the time of this report (February $5^{\text {th }} 2021$ ), Nigeria has recorded 137,654 confirmed cases, 111,639 discharged cases and 1641 deaths. (NCDC, 2021). There is no medical curative procedure for covid-19 yet, however, preventive measures to stop its spread include; alcohol-based sanitizer frequently; maintaining social distance of not less than 2 meters; using face masks; avoiding facial contact with an infected person; not touching your face; coughing into your elbow; staying at home if you can; seeking medical care early in febrile condition, cough, and difficulty in breathing; throwing used tissues in the trash; cleaning and disinfecting frequently touched surfaces; staying informed; and following advice given by a health-care provider, ( Nigeria was affected by the Corona virus pandemic. Within the year 2020, Nigerian government imposed several restrictions as a measure to combat the spread of Covid-19. These measures include; ban on public gatherings including church worship to closure of schools, ban on interstate travels, etc. This measure also affected many businesses especially supply of livestock and poultry inputs such as; feeds, day old chicks, equipment and supplies leading to various effects on livestock and poultry inputs, and products. This drastically affected the forces of demand and supply and consequently affected price mechanism. This study, aimed at investigating the effects of Covid19 pandemic on poultry production in the South-East agro-ecological zone of Nigeria

\section{Materials and methods Location of study}

The study was conducted in South-East, Nigeria. The area is located within latitudes $5^{\circ} \mathrm{N}$ to $6^{\circ} \mathrm{N}$ of the equator and longitudes $6^{\circ} \mathrm{E}$ and $8^{\circ} \mathrm{E}$ of the Greenwich (prime) meridian 


\section{Esiegwu and Ejike}

(M.S Corporation, 2009). The zone occupies a total land mass of $10,952,400$ hectares with a population of $21,955,414$ people (NBR, 2017). The zone experiences an average annual temperature, rainfall and relative humidity of $27^{\circ} \mathrm{C}, 1800 \mathrm{~mm}$ and $72 \%$, respectively. Despite the observed erratic nature of both rainfall and dry spells brought about by climate change, the location of the zone within the tropical rainforest belt of the country allows and provide support for the growth and survival of most tropical food crops such as; cassava, yam, maize, vegetables, oil palm, plantain, rice, etc, and livestock production like poultry, piggery, goat, etc. The inhabitants of the zone are predominantly engaged in agriculture, mainly crop farming and animal rearing. The zone houses one of the largest commercial hub centre (Onitsha main market) in the country and also one of the region threatened by the Covid-19 pandemic with over 6906 confirmed cases, 101 deaths and 5212 discharged cases as at $5^{\text {th }}$ February, 2021 (NCDC, 2021).

\section{Data collection}

Primary data were collected with the aid of questionnaire and an interview guide. The population for the study were poultry farmers, participants in the hatchery subsector, feed sub-sector, and poultry marketers. The study was conducted in October 2020 through January 2021. Multistage sampling procedure comprising purposive and random sampling techniques were employed to select respondents for the study. Two States out of the five states that make up the southeast zone namely, Imo and Enugu States were purposively selected based on concentration and availability of all four categories of respondents. Two Local Government Areas (LGAs) were purposively selected from each of the states based on presence of all four categories of respondents for the study making a total of four LGAs. One community was purposively selected from each LGAs based on the availability of the respondents bringing the total number of communities to four. A total of 120 respondents comprising of 15 poultry farmers, 15 marketers where randomly selected from each of the communities while 4 poultry feed millers and 3 poultry hatcheries that were available were all selected (purposively)for the study. The lists of the respondents were obtained from the Agricultural Development Project (ADP) office in the respective States and these formed the sample frame for the study. Focus Group Discussion (FGD) and Indepth Interview (IDI) were also employed to elicit data for the study. All hatcheries and feed millers censored for the study were engaged only in FGD and IDI. A total of ten participants were engaged in a focus group discussion (FGD), one from the hatchery subsector, two feed millers, three marketers and four poultry farmers were selected from each State. An In-depth interview (IDI) was conducted on two poultry feed millers and one poultry hatchery censored for the study bringing the total sample size for the study to one hundred and fifty (150). Covid-19 precautionary measures of social distancing, use of face mask and hand washing with sanitizer were strictly observed during the data collection process.

\section{Data analysis}

Data analysis was carried out using the mean score analysis with a 4-point likert type scale of Strongly agree (4), agree (3), disagree (2) and strongly disagree (1) with a mean cut-off point (discriminatory index) of 2.50 , that is, $4+3+2+1=10 / 4=2.5$ cutoff point. Content analysis was also used to analyse the qualitative data gathered from FGD and IDI. Data collected from IDI via voice recordings were transcribed and synthesized and the information generated was organized into sub-themes. 


\section{Effect of COVID-19 on poultry production in south east agro-ecological zone of Nigeria}

Results and discussion

\section{Effects of Covid-19 on poultry production} subsector

Covid-19 pandemic is a multiplier of vulnerability presenting enormous threats to and across the agricultural food value chain system and the actors in the food chain particularly the poultry industry. The situation continues to change rapidly and varies widely across regions of the country, particularly as 'second waves' of Covid-19 spread are emerging. This segment of the study looks into the effect of Covid-19 on poultry production. The estimated result on effect of Covid-19 on poultry production is presented in Table 1.0 and complemented with information retrieved from the focus group discussion (FGD) and an in-depth interview (IDI). Mean value above the cutoff point of 2.5 suggesting that the various Covid-19 pandemic attributes highlighted have an adverse effect on poultry production in the study area as perceived by the respondents. The result in Table 1.0 is further buttressed by the values of standard deviation which indicate the variation in the response of the poultry producers. Standard deviation value of less than 1 or equal 1 suggests closeness or agreement in the opinion of the respondents regarding specific attribute resulting from Covid-19 pandemic while standard deviation value above 1 suggest a high dispersion in the response of the respondents towards the possible perceived effect of Covid-19 pandemic. The attribute; Covid-19 pandemic have resulted in high labour cost due to movement restriction with a mean score of 3.45 and a standard deviation value of 0.99 was strongly acknowledged by one of the participant in the FGD who narrated that;

"Farm production has been affected greatly by inputs, most notably is labour. The cost of labour became very expensive; I find it difficult to get workers during the pandemic because of the restriction placed on movement and cost of transportation. The few workers I hired that work with me even barely come to work. Sometimes I have to resort to doing most of the labour myself and in some cases my wife and children assist me to attend to the birds. I could not also meet up sales because of untimely operation of activities resonating from inadequate manpower and that affected the returns I expected from my production".

Table 1.0 shows the result on effects of Covid-19 on poultry production. Using mean score analysis with a 4-point likert type scale of strongly agreed (4), agreed (3), disagreed (2) and strongly disagreed (1), the result reveals that all the items in the scale indicated an acceptable. Table 1.0 also revealed that the attribute; Covid-19 spiked up the cost of feed with a mean value of 3.95 and a standard deviation value of 0.21 is an indication that poultry feed constitutes a major input material in poultry production which according to Oladokun (2012) accounts for $70 \%$ of total cost of production in poultry. The costs for feed strongly depend on the ingredient prices, which can fluctuate throughout the year. Survey report have it that the costs of producing major crops generally increased across the country, by as much as $167 \%$ as a result of high input cost occasioned by the economic restrictions imposed globally due to Covid19 (NAERLS and FMARD, 2020). Information gathered from a participant in the FGD indicated that;

"production in my farm was specifically impacted by high cost of inputs materials particularly feed. During the pandemic the price of maize and soya was so high and that affected feed formulation in my farm. Another area of challenge I had was access to markets as a result I could not secure enough market for my poultry birds". Another respondent said "I used to buy broiler starter feed \#3500 but during this Covid-19 period, I bought them \#5500 and 


\section{Esiegwu and Ejike}

Table 1.0: Effect of Covid-19 pandemic on poultry production

\begin{tabular}{|c|c|c|c|c|}
\hline \multirow{2}{*}{$\begin{array}{l}\mathrm{S} / \mathrm{N} \\
1 .\end{array}$} & Mean & Mean Score & \multicolumn{2}{|c|}{ Standard Deviation Decision } \\
\hline & $\begin{array}{l}\text { Covid } 19 \text { pandemic poses a serious } \\
\text { Threat to our health }\end{array}$ & 3.44 & 0.98 & Accepted \\
\hline \multirow{19}{*}{2.} & $\begin{array}{l}\text { High cost of product delivery as a result of } \\
\text { movement restriction and transportation cost }\end{array}$ & 2.91 & 1.13 & Accepted \\
\hline & $\begin{array}{l}\text { Covid-19 have resulted in the reduction/scarcity } \\
\text { of labour availability due to movement restriction }\end{array}$ & 3.25 & 0.98 & Accepted \\
\hline & $\begin{array}{l}\text { Covid-19 have resulted in high labour cost due } \\
\text { to movement restriction }\end{array}$ & 3.45 & 0.99 & Accepted \\
\hline & $\begin{array}{l}\text { Covid-19 resulted in hike in purchase } \\
\text { price of day old chicks }\end{array}$ & 3.65 & 0.77 & Accepted \\
\hline & Covid-19 spiked up the cost of feed & 3.95 & 0.21 & Accepted \\
\hline & Covid-19 affected my access to market & 3.41 & 0.74 & Accepted \\
\hline & $\begin{array}{l}\text { Covid- } 19 \text { resulted in high cost of drugs and } \\
\text { medication }\end{array}$ & 3.36 & 0.82 & Accepted \\
\hline & $\begin{array}{l}\text { Covid-19 resulted in rise in the cost of } \\
\text { equipments used for production }\end{array}$ & 2.68 & 1.21 & Accepted \\
\hline & $\begin{array}{l}\text { Covid-19 resulted in increase of aggregate } \\
\text { production cost }\end{array}$ & 3.13 & 0.96 & Accepted \\
\hline & $\begin{array}{l}\text { Covid-19 have brought about reduction in } \\
\text { growth weight of birds due to high cost of feed }\end{array}$ & 2.61 & 1.09 & Accepted \\
\hline & $\begin{array}{l}\text { Covid-19 have resulted in longer } \\
\text { production period due to poor weight } \\
\text { of birds resulting from scarcity of } \\
\text { feed. }\end{array}$ & 2.70 & 0.94 & Accepted \\
\hline & $\begin{array}{l}\text { Covid } 19 \text { affected poultry egg production } \\
\text { due to poor feeding as a result of scarcity of } \\
\text { of feeds and high cost. }\end{array}$ & 2.88 & 0.82 & Accepted \\
\hline & $\begin{array}{l}\text { Covid-19 resulted in influx of new entrants into } \\
\text { the business due to festivity }\end{array}$ & 3.86 & 0.34 & Accepted \\
\hline & $\begin{array}{l}\text { Covid-19 resulted in decline in sales of table } \\
\text { to low demand }\end{array}$ & 3.50 & 0.83 & Accepted birds due \\
\hline & $\begin{array}{l}\text { Covid-19 resulted in decline in sales } \\
\text { of table eggs due to hike in price } \\
\text { of poultry egg as a result of production cost }\end{array}$ & 3.26 & 0.79 & Accepted \\
\hline & $\begin{array}{l}\text { Covid- } 19 \text { have resulted in reduced farm income a } \\
\text { a result of poor sales }\end{array}$ & as 2.90 & 0.98 & Accepted \\
\hline & $\begin{array}{l}\text { Covid-19 resulted in dumping due to } \\
\text { low demand }\end{array}$ & 2.73 & 0.79 & Accepted \\
\hline & $\begin{array}{l}\text { Covid-19 resulted in high cost of transportation } \\
\text { due to movement restriction and lockdown }\end{array}$ & 2.61 & 0.84 & Accepted \\
\hline & $\begin{array}{l}\text { Covid-19 resulted in increased price of finished } \\
\text { product due to high cost of production }\end{array}$ & 2.98 & 0.83 & Accepted \\
\hline
\end{tabular}

even broiler finisher feed which was \#3300, consumption. It is one of the core activities Inow bought them \#5000”.

\section{Effect of covid-19 on poultry marketing subsector}

Marketing is an economic activity which ensures the transfer of goods and services from the point of production to the point of being carried out in the poultry industry. This section looks into the effect of Covid19 pandemic on poultry marketing. The estimated result of the mean score analysis which was achieved using a 4-point likert type scale of strongly agreed (4), agreed (3), disagreed (2) and strongly disagreed (1) is presented in Table 2.0. 


\section{Effect of COVID-19 on poultry production in south east agro-ecological zone of Nigeria}

Table 2: Effect of Covid-19 on poultry marketing

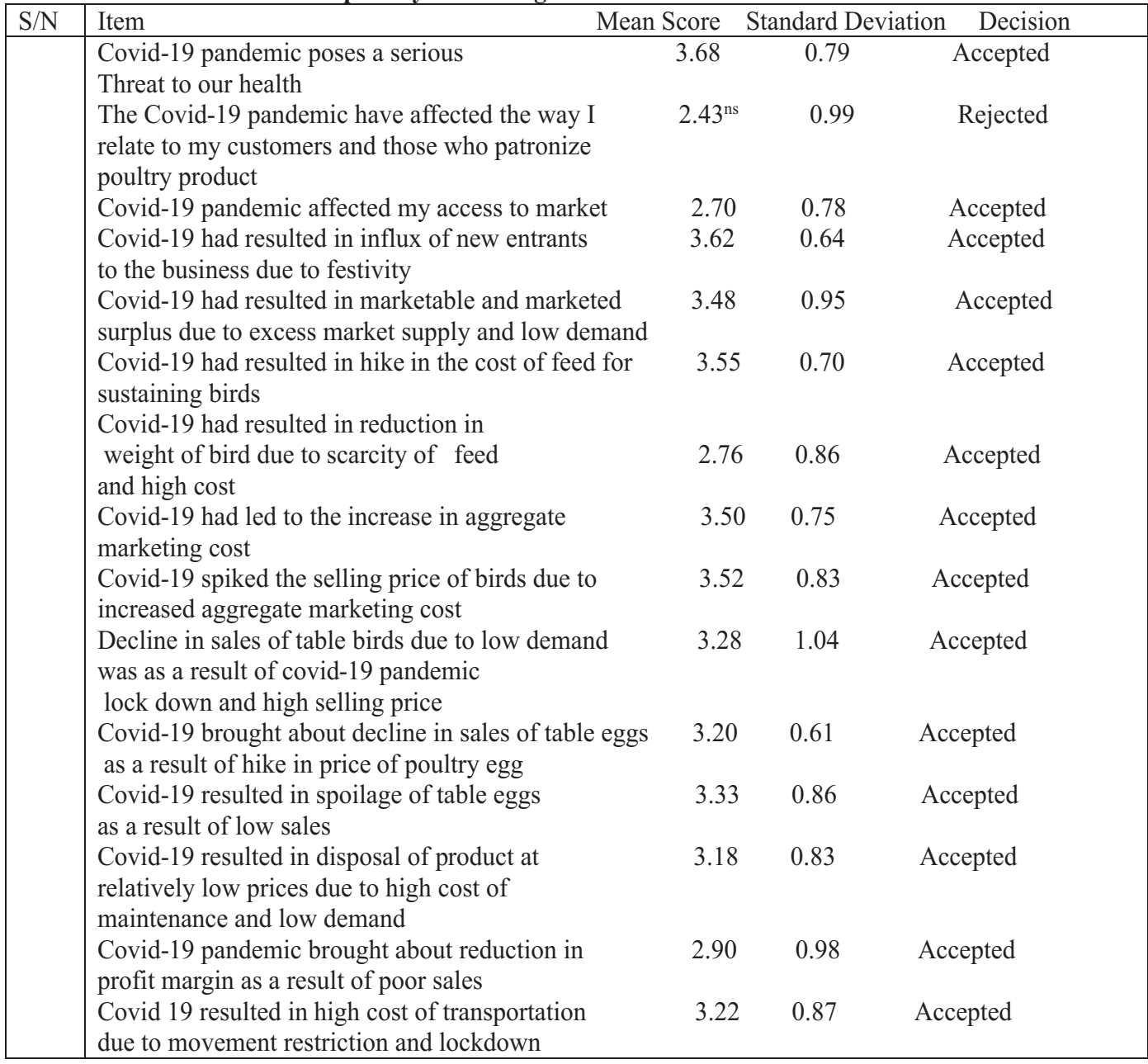

Source: Field survey data, 2021. $n s=$ not significant, $n=60$

The result from the mean score analysis presented in Table 2.0 reveals that all the items in the scale indicated an acceptable mean value above the 2.5 cut-off point implying that the Covid- 19 pandemic have impacted on the poultry traders marketing operations except for the attribute Covid-19 pandemic have affected the way I relate to my customers which have a mean score of 2.43 and a standard deviation value of 0.99 implying that despite the pandemic the traders still relate with their customers. The result in Table 2.0 further revealed that the item Covid-19 pandemic poses a serious threat to our health top the chart in the scale with a mean score of 3.68 and a standard deviation value of 0.79 . This result is strengthened by one of the participants in the FGD who opined that;

"I am aware of the dangers of Corona virus disease to my health and the possibility of contacting the virus through contacts with people but the nature of my business which is associated with bad odour and dust particles many a times make it difficult for me to put on my face mask because it's difficult for me to breathe with it and speak clearly to customers". 


\section{Esiegwu and Ejike}

Another attribute of the effect of Covid-19 on poultry marketing is the increase in aggregate marketing costs which has an acceptable mean value of 3.50 and a standard deviation of 0.75 . The low variation in the opinion of the marketers could be as a result of transportation hike and rise in the cost of feed. This correlates the views of one the FGD participant;

"Poultry marketing have been badly hit by the Corona virus pandemic occasioned by supply and price volatility. The prices of poultry birds are higher than pre-pandemic period. For instances we use to sell an average table bird of weight $2.5 \mathrm{~kg}$ at \#2,300 but during the pandemic such weight of bird goes for $\$ 5000$ due to higher operating costs as a result of hike in transportation and feed cost which resulted in trade disruption.

\section{Effect of Covid-19 pandemic on hatchery subsector}

This section takes into account the effect of Covid-19 pandemic on the hatchery industry. Results from the FGDs and IDI indicated that within the period of Covid19 , the costs of raw materials sky rocketed. The major cost was expenses on power. Averagely it took " 120 against " 80 to produce one chick as a result of cost of fertile egg. The rise in soya and maize visa vis cost of feed and drug. Hatchery operations during the pandemic witnessed a decline in labour availability. A lot of casual workers were not willing to work and those available were finding it difficult to come to work due to movement restrictions and curfew as a result the daily pay for labour increased drastically as the available workers had to hike their daily wage. In addition, the Covid-19 pandemic safety protocols implemented reduced labour mobility and availability. There was also decline in sales of chicks. Transportation and logistics impacted on production. In many occasions production could not be exhausted due to restriction of movement even when the restrictions were relaxed, traffic jam became an issue resulting in the suffocation of the chicks on transit. One of the participants in the FGD narrated;

"some of my workers were not coming to work due to cost of transportation. The delivery and supply of chicks were cut-off from distance customers due to transportation cost and fear of death of chicks" Even when the farmers needed the birds, supply could not be met because of means of transporting it and high logistics cost involved"

The civil unrest in some parts of country particularly that of Rivers State during the pandemic period also contributed to the decline in sales as supply could not be made in the area which is a major sales outlet which consequently resulted in dumping. The high cost of feed resulted in dumping. There was a lot of egg glut as a result of drop in table egg consumption. Many businesses and institutions that patronize table eggs were on lock.

"Covid 19 has led to a drastic shift in consumer demand for egg. In many places, loss of demand and difficulties in reaching consumers due to distance has led to volatile prices. The total shutdown of schools, hotels, fast food centres and restaurants during the period of the pandemic has also jointly affected table egg demand resulting in substantial decline in sales and egg glut" (hatchery IDI)

\section{Effect of Covid-19 pandemic on feed mill} subsector

Feed is the most important input in poultry production and in the poultry industry in general, accounting for over $70 \%$ of the total cost of production. According to information gathered from the FGD and IDI, the main concerns for the majority of the participants in the FDG and IDI for hatchery subsector was input availability 


\section{Effect of COVID-19 on poultry production in south east agro-ecological zone of Nigeria}

and price. According to them feed production have been very expensive during the period of the pandemic. The price of raw materials for production recorded a hike. Sales reduced significantly occasioned by a fall in demand and many of the feed millers were folding up production as a result of hike in inputs required for production. Among the participants in the FGD, a feed miller pointed out;

"Covid 19 has inflicted a serious shock on all segments of the poultry industry, affecting both production, processing, milling, marketing, transport and logistics, and the overall demand for poultry products. During the first wave of covid-19, production of poultry feed became quite expensive. The price of raw materials needed for production was very high. While the prices of palm kernel cake and fish meal remain relatively constant, the price of maize rose drastically from $\$ 110$ preCovid-19 to $\$ 220$. Soya bean rose from $\# 75$ to $\$ 290$. Price per bag of starter feed rose from $\$ 4200$ to $\$ 7000$, finisher rose from \#3500 to $\$ 6000$. Vitamin premix starter also recorded an increase in price from \#600 to $\$ 2700$. In the same vein, sales reduced drastically due to low patronage. Many feed millers have to stop production because of high production cost"

\section{Conclusion}

Covid-19 had a negative impact on the reviewed subsectors of the poultry industry from production to marketing, to hatchery and to feed milling based on the findings of the study. It was concluded that Covid-19; resulted in scarcity of inputs and high cost of raw materials (feed ingredients, drugs equipment and supplies) leading to high cost of production and high selling price. It also resulted in difficulty in accessing the markets leading to dumping of poultry products and egg glut. The result also revealed that the respondents all perceived Covid-19 to having an adverse effect on their business given the mean score value which was above the cut-off mark of 2.5. While the effect of Covid-19 are still unfolding given that the country is in its second phase of the pandemic and in the light of challenges in the industry portend by the pandemic, there is a considerable concern about the survival of the subsector. The study calls for pragmatic and proactive action to reduce and control the effect of the pandemic and keep the industry going.

\section{Recommendation}

Based on the findings of the study, it was therefore, recommended that;

a. Government should incentivise the production of maize, soya, and other raw materials for feed production through an effective input subsidization to ensure costeffective production that will encourage continued and sufficient supply to other sub-sectors in the poultry industry.

b. Government and other development agencies/partners should intervene by providing the needed infrastructures (egg processing machine) that can process egg to eliminate egg glut or waste in general.

c. governments should facilitate the movement of workers and agricultural food products to ease the burden of actors in the industry

d. Poultry industry players should maintain the health and safety of both themselves and their employees by ensuring Covid-19 safety measures are adhered to.

\section{References}

Adhikari, S. P., Meng, S., Wu, Y. J., Mao, Y. P., Ye, R. X., Wang, Q. Z. and 
Raat, H. 2020. Epidemiology, causes, clinical manifestation and diagnosis, prevention and control of coronavirus disease (COVID19) during the early outbreak period: A scoping review. Infectious Diseases of Poverty, 9(1), 1-12. Available at: https://doi.org/10.1186/s40249\begin{tabular}{lllllllllll}
\hline 0 & 2 & 0 & - & 0 & 0 & 6 & 4 & 6 & $-\mathrm{x}$. \\
\hline
\end{tabular}

Congressional Research Service. 2020. Global economic effects of COVID-19. Retrieved from https://fas.org/sgp/crs/row/R46270 pd f. $1-78$.

Gallagher, J. 2020. Coronavirus symptoms: What are they and how do I protect myself $\square$ Retrieved from h t t p s : // w w w. b b c . com/news/health-51048366.

Minnesota Department of Health. 2020. Symptoms and testing: COVID-19. $\mathrm{R}$ e t $\mathrm{rie}$ e e d from : https//www.health.state. mn.us/diseases/coronavirus/sympt o $\mathrm{m} \quad \mathrm{s}$. $\mathrm{h} \quad \mathrm{t} \quad \mathrm{m} \quad 1$.

NAERLS AND FMARD, 2020. Wet Season Agricultural Performance in Nigeria. NAERLS Press, Zaria.

NBR, 2017. National Bureau of Statistics. Population figures. Demographic Statistics Bulletin Nigeria
NCDC (Nigeria Centre for Disease Control), 2020. First Case of Corona Virus Disease Confirmed in Nigeria. NCDC, Abuja, Nigeria. Downloaded on March 30th 2020 $\begin{array}{llll}\mathrm{f} & \mathrm{r} & \mathrm{o} & \mathrm{m}\end{array}$ https://ncdc.gov.ng/news/227/first -case-of-corona-virus-diseaseconfirmed-in-nigeria.

NCDC (Nigeria Centre for Disease Control) 2021 . Covid19 . N C D C. g o v. n g.

Oladokun, 2012. Feed formulation problem in Nigerian poultry farms: a mathematical programming

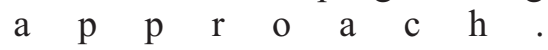

WHO. 2020b. Coronavirus disease (COVID-19) advice for the public. Retrieved from https://www. who.int/e merge n c i es /diseases/novel-coronavirus$2019 /$ advice-for-public

Received: $12^{\text {th }}$ October, 2020 Accepted: $5^{\text {th }}$ February, 2021 